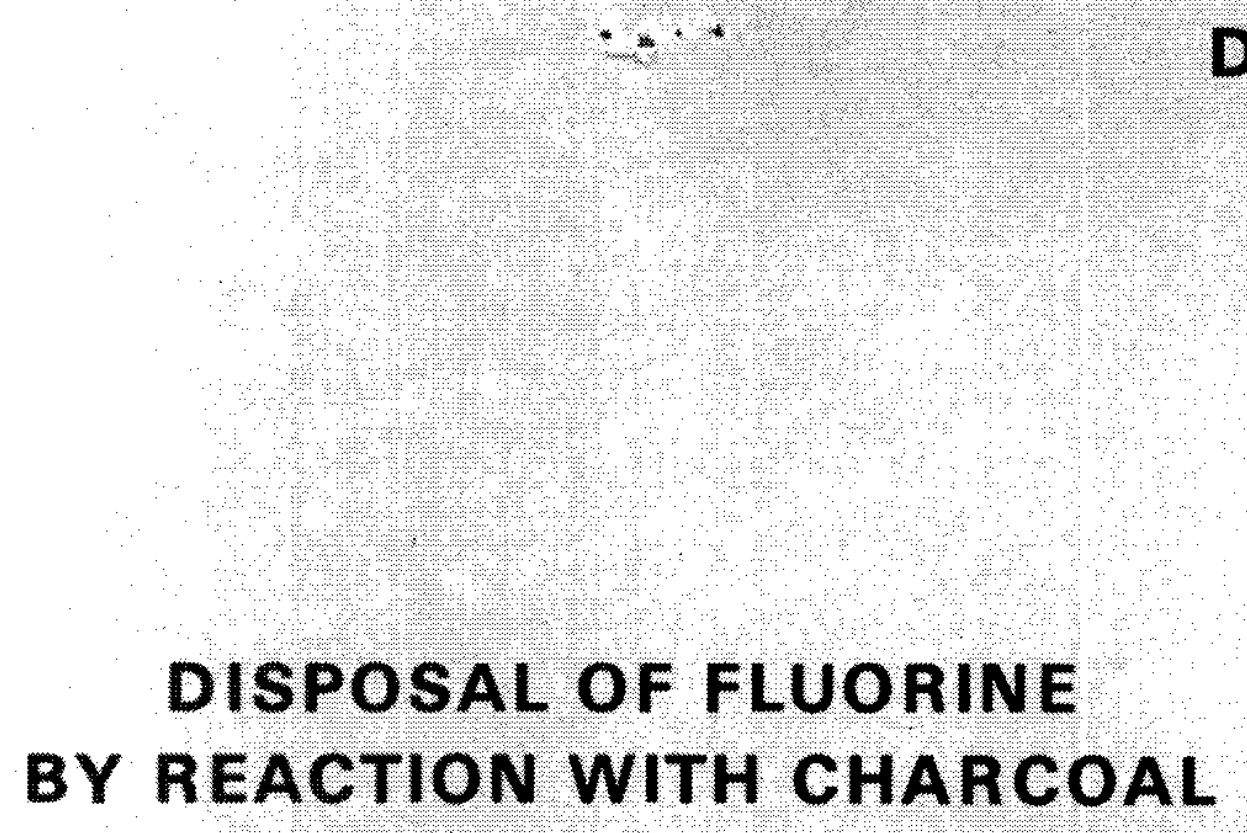

DP-1359

J. A. KELLEY

TIS FILE RECORD COPY

E. 1. du Pont de Nemours \& Co. Savannah River Laboratory Aiken, S. C. 29801

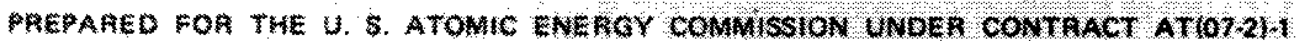




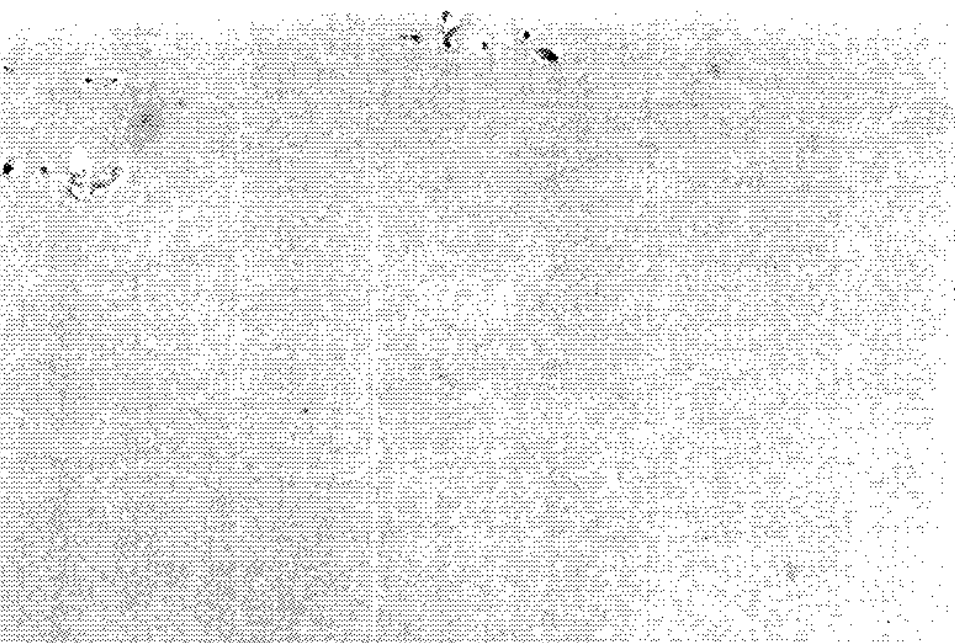

NOTICE

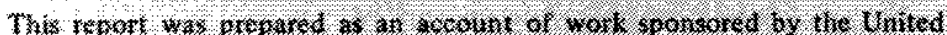

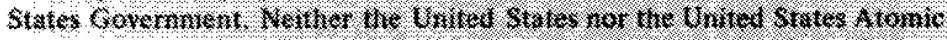

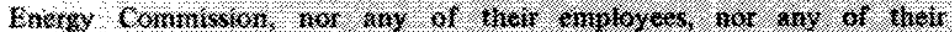

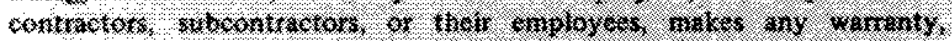

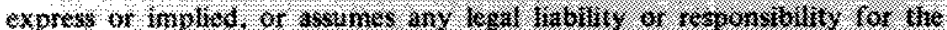

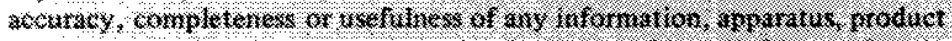

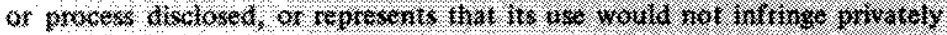
owned bithes

Printed in the United States of America Avallable trom

National Technical information Service

U, S. Depaxtment of Commerce

$\$ 285$ Port Royal Road

Springtield, Virginta 22131

Price: Printed Copy 84.00, Microfiche $\$ 1.45$ 
DP-1359

UC- 4

\title{
DISPOSAL OF FLUORINE BY REACTION WITH CHARCOAL
}

\author{
J. A. Kelley \\ Approved by \\ J. A. Porter, Research Manager \\ Separations Chemistry Division
}

Publication Date: August 1974

E. 1. du Pont de Nemours \& Co.

Savannah River Laboratory

Aiken, S. C. 29801

PAEPARED FOA THE U. S. ATOMIC ENERGY COMMISSION UNDEA CONTAACT ATIO7-2)-1 


\begin{abstract}
Tests were made to determine the type of charcoal and operating parameters best suited for fluorine disposal. Nonactivated wood charcoal was found to be safe in operation, and heating of the charcoal to $\$ 300^{\circ} \mathrm{C}$ was necessary for efficient reaction of fluorine. At low fluorine concentrations $\left(<25 \% \mathrm{~F}_{2}\right.$ in the gas stream), the principal reaction product is a whte fluorocarbon smoke. $C_{4}$ 1 s the principal product with $100 \%$ fluorine. A small amount of condensable fluorocarbons is formed by the fluorine-charcoal reaction.
\end{abstract}




\section{CONTENTS}

\section{Page}

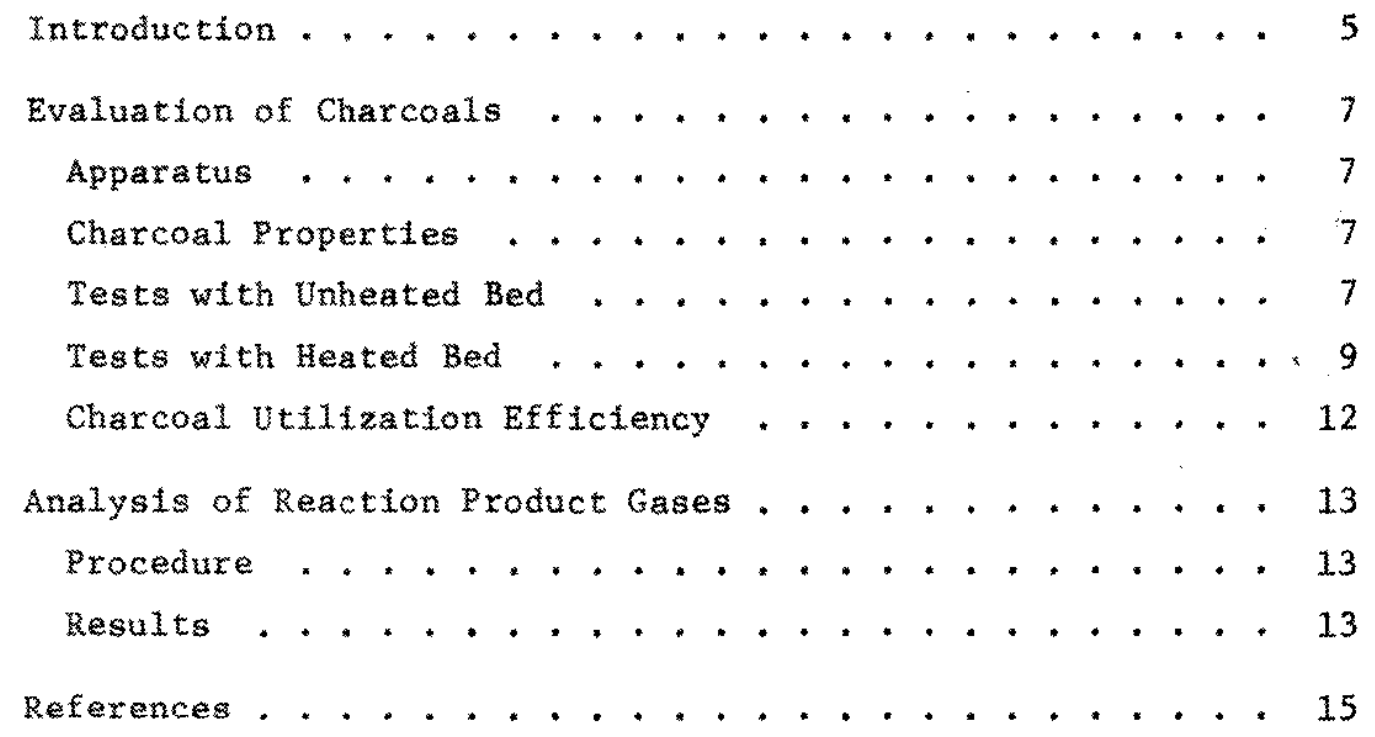




\section{LIST OF TABLES AND FIGURES}

Table

Page

1. Properties of Charcoals Tested for Fluorine Dlsposal ................... 9

II Sumary of Fluorine Disposal Tests in Heated Charcoal Trap .............. 10

III Effect of Temperature on Fluorine Disposal with Nonactivated Wood Charcoal (Number 4) . , 11

IV Charcoal Consumption and Restdue Formation . . 12

V Compostion of Charcoal-Fluorine Reaction Product Gases ............. 14

Figure

1 Apparatus for Fluorine-Charcoal Tests . . . . 8 


\section{INTRODUCTION}

Safe disposal of waste gases containting elemental fluorine is a common problen among industries using this very reactive and toxic gas. Most of the common methods, such as caustic scrubbing, burning, chemical converston to chlorine by reaction with sodium chloride, and reaction with activated alumina, form byproducts that also present disposal problems. ${ }^{2}$ one of the simplest and most economical methods of fluorine disposal is based on the reaction of wod charcoal with fluorine to produce nontoxic fluorocarbons, which can be vented to the atmosphere. The primary product of the reaction between fluorine and charcoal is $\mathrm{CF}_{4}$ with small amounts of higher fluorocarbons. ${ }^{2}$ Heated ${ }^{2}$ and unheated ${ }^{3}$ charcoal traps have been used at several sttes for fluorine disposal.

Standifer et al." have used activated wood charcoal in unheated traps for fluorine disposal. Pulley and Harris ${ }^{*}$ recomended nonactivated wood charcoal heated to $125-300^{\circ} \mathrm{C}$. Explosions were reported wh thetivated charcoals and low fluorine concentrations. rhe explostons were attributed to the rapid reaction of a large quantity of adsorbed fluorine with charcoal after the reaction was Initiated by increasing the fluotine concentration. "This hypothesis was confirmed by several observations:

- Nonactivated charcoals with low surface areas (and thus lower capacity for fluorine adsorption) did not explode when reacted wh fhluorine under the same conditions.

- The residual fluorine concentration in unreacted activated charcoal was much higher than that in nonactivated charcoal.

- Wuorine adsorbed on activated charcoal could be removed by purging; then the chaxcoal did not explode when the fluortne concentration was sharply increased.

Published data do not adequately define trap operating conditons, such as temperature and fluorine flow, for efficient fluorine disposal. Data for the composttion of reaction product gases at vartous operating conditions are also incomplete. The present study was undertaken to clarify these uncertainties. 


\section{EVALUATION OF CHARCOALS}

\section{APPARAUS}

Several types of wood charcoals and sintered coke were tested for lluorate disposal in the apparatus shown in Figure 1. Charcoal was supported by a ckel screens in a nickel column 0.87 inch in dianeter and 12 inches long. A callbrated Hastings-Raydist mass

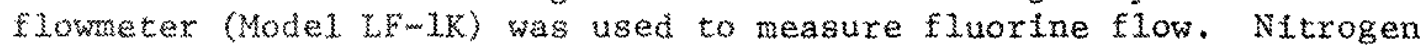
Fow was measure wh a calibrated rotameter. Fluorine-nitrogen mixtures were passed through baffled mixing chambex before reaction wh charcoal. Unreacted fluorine in the charcoal column effucht was reacted wh activated $\mathrm{Al}_{2} \mathrm{O}_{3}$ or, in some cases, with

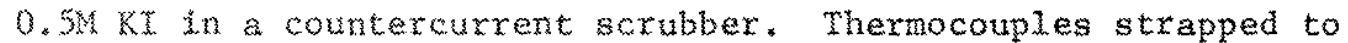
the outsde wall of the colum were used to monitor temperature. wance tests, the column was heated with clamshel1 heaters.

\section{CHARCOAL PROPERTIES}

Properties of chatcoals tested are given in Table I. Charcoals received as large humps were ground and sieved to size. Charcoals 6 and 7 were purifled from traces of volatile hydrom carbons by heating at $950^{\circ} \mathrm{C}$ in a nitrogen purge, as recommended by pulley and clarks." Sintered coke, hard, brittle material, was 1 as tested becaluse of 1 ts low surface area. Surface areas of charcoals were measured by the nitrogen aboorption method.

\section{TESTS WWH UNHEREO BED}

Asmrecelved charcoals were tested in an unheated column wh a bed depth of 10 to 12 inches. Nutrogen and fluorine (5-100\%) were passed through the colum to determine maximum flow without appearance of fluorine in the effluent (breakthrough) and to determine steday-atate operating temperatures. Fluorine breakthrough fos cased by incomplete reaction of fluorine with chatcoal at low temperature and high flow. Fuorine breakthrough was determined wh KT-saturated paper, which can detect fluorine at $>25$ ppm.

Charcouls and 2 (activated wood) reacted with fluorine wht no breakhwough, but water driven from the fluortne-charcoal reaction zome and charcoal fines increased the pressure drop across the bed. Charcolis 3 and 4 (nonactivated wood) reacted with fluorine 


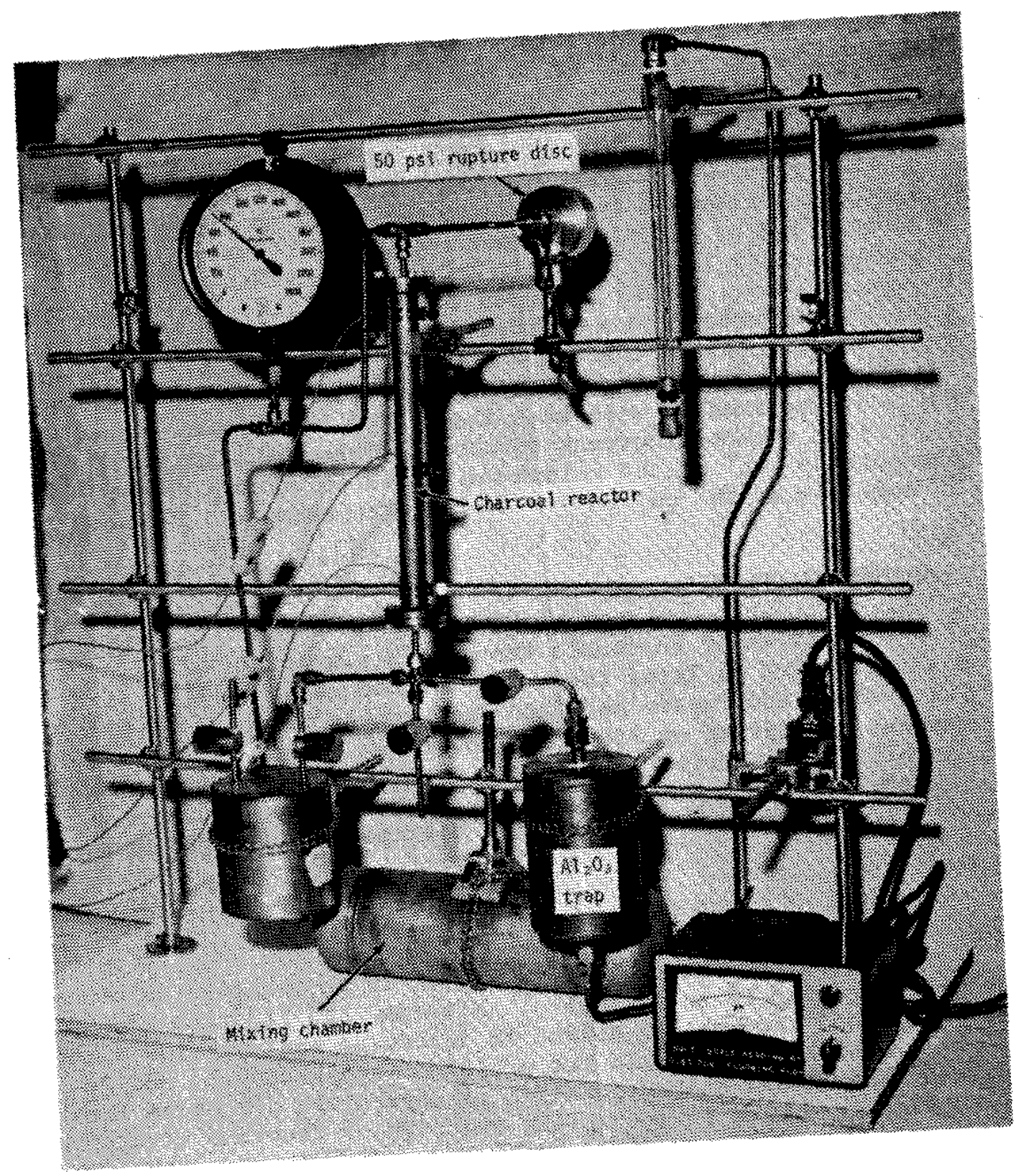

Flgure 1. Apparatus for Fluorine-Charcoal Tests 
TABLE :

Praturties of harcols lested for Fluorine Disposal

\begin{tabular}{|c|c|c|c|c|c|c|c|}
\hline Sugsiper & Yrose & Vendor & $\begin{array}{l}\text { West } \\
512 \pi \\
\end{array}$ & $\begin{array}{c}\text { gulk } \\
\text { Dens } \\
g / 5,\end{array}$ & $\begin{array}{c}\text { Surface } \\
\text { Area, } \\
{ }^{2} / 9\end{array}$ & $\begin{array}{c}\text { sarbon, } \\
3 \\
3\end{array}$ & $\begin{array}{c}\mathrm{H}_{2} \mathrm{O}, \\
\mathrm{F}\end{array}$ \\
\hline 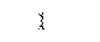 & Actsvated wats & 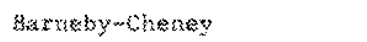 & $4-8$ & 0.34 & 580 & 89.0 & $\sin 32$ \\
\hline ? & Aerivated wood & barroebyuranencey & $2-4$ & 0.27 & 485 & 89.0 & $5-10$ \\
\hline 3 & 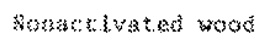 & Barnabywehanay & $4 \div 8$ & 0.23 & 370 & 79.9 & $2-4$ \\
\hline 4 & 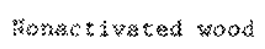 & 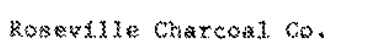 & $2 w g^{2}$ & $0.2 x$ & 93 & 77.1 & 1.5 \\
\hline$\hat{3}$ & Nonactitated soowis & Cromectout chareoa $\mathrm{Co}$. & $2 m 8^{k}$ & 0.29 & 3 & 73.6 & $0.5-3$ \\
\hline 8 & 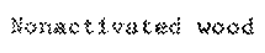 & âserinde charcoal co. & $2 m 8$ & $\sim$ & 144 & 96.6 & $r$ \\
\hline$z^{3}$ & Nowactivatad wood & Connedracut oharcoal co. & $2 \sim 8$ & $m$ & 12 & 93.7 & - \\
\hline 8 & Sintaxes coke & 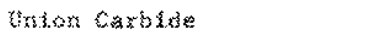 & $2 m 8$ & $\sim$ & 3 & 75.3 & $m$ \\
\hline
\end{tabular}

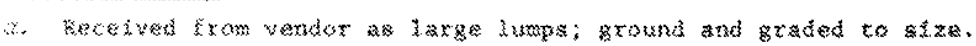

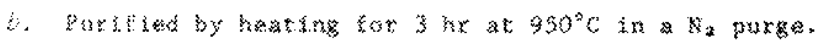

and prevented breakthrough until the bed dried, at which time the charcon was very inefictent for fluorine disposal. In previous study," wimlar results with nonactivated wood charcoals were reportad. Burng these tests, the 1/4-1 rich-diameter outlet line from the colum period cally became pugged with condensable fluorocarbons formed by the incomplete reaction of charcoal with Luorine.

\section{TESTS WTH HEATEO BED}

Ang charcod bed. During a test with charcoal 1 (activated wood), an axplosion occurred that burst the 50 psi rupture dise (with no Gurther damage?. Before the explosion, the column was heated to $200^{\circ} \mathrm{c}$, and $4 \%$ fluorine was passed through the bed for 220 minutes. The zuorine concentration was then quickly increased to $40 \%$, and the explosion occurred. There was a large quantity of charcoal fines in the bed after the explosion. Charcoals 1 and 2 were not considered further because of the explosion hazard. Tests were made wh charcols 3,4 , and 5 at the same conditions that caused charcoal I to explode; none of these samples exploded.

Table. II summarizes the results of other tests with a heated column. These results demonstrate that nonactivated wood charcoals should be heated to $>200^{\circ} \mathrm{C}$ for efficient fluorine disposal at low fluorine concentrations. At an initial temperature of $300^{\circ} \mathrm{C}$, no fluortne breakthrough occurred with a 10 - to 12 -inchdeep charcoal bed even at very high flows. Sintered coke did not react appreciably with fluorine below $400^{\circ} \mathrm{C}$. 
TABLE IH

Sumary of Fluorine Disposal Tests

in Heated Charcoal Trap

\begin{tabular}{|c|c|c|c|c|}
\hline \multirow[b]{2}{*}{$\begin{array}{l}\text { Dharcoal } \\
\text { Samplea }\end{array}$} & \multirow[b]{2}{*}{$F_{2} x_{m}$} & \multirow[b]{2}{*}{$\begin{array}{c}\text { Initial Bed } \\
\text { Temperature, }{ }^{~} \mathrm{C}\end{array}$} & \multicolumn{2}{|c|}{ Elworine Breakthrough Conditions } \\
\hline & & & $\begin{array}{l}\text { Gas feed Rate, } \\
\text { cc/min at } \\
\text { u atm, } 25^{\circ} \mathrm{C} \\
\end{array}$ & $\begin{array}{l}\text { Superficlal gas } \\
\text { Veloclty, ft/min }\end{array}$ \\
\hline 4 & 5 & 100 & $<300$ & $<3.2$ \\
\hline 4 & 35 & 100 & $<180$ & $<1.9$ \\
\hline 4 & 25 & 100 & $<200$ & $<2.1$ \\
\hline 4 & 50 & 100 & $<140$ & $<1.5$ \\
\hline 4 & 100 & 100 & $\sim 100$ & ט.1 \\
\hline 4 & 5 & 200 & 290 & 4.0 \\
\hline 4 & 15 & 200 & 680 & 9.3 \\
\hline 4 & 25 & 200 & 700 & 9.5 \\
\hline 4 & 50 & 200 & $800^{\circ}, d$ & $>11^{\circ, d}$ \\
\hline 4 & 200 & 200 & $800^{\circ}, d$ & $>110, d$ \\
\hline 4 & 0.5 & 300 & $>7,000^{\circ}$ & $>1 x y^{2}$ \\
\hline 4 & 1 & 300 & $>6,000^{\circ}$ & $>100^{\circ}$ \\
\hline 4 & 5 & 300 & $>10,000^{\circ}$ & $>167^{\circ}$ \\
\hline 4 & 15 & 300 & $>4,700^{\circ}$ & $>78^{\circ}$ \\
\hline 4 & 50 & 300 & $>600^{\circ} * a^{2}$ & $>10^{c}, c^{2}$ \\
\hline 4 & 100 & 300 & $>600^{\circ}, 2$ & $>10^{e}, 2$ \\
\hline 5 & 1. & 100 & $<1,000$ & $<\mu$ \\
\hline 5 & 5 & 100 & $<300$ & $<3.2$ \\
\hline 5 & 2.5 & 200 & 21,000 & 013.6 \\
\hline 5 & 2 & 250 & 04,500 & 268 \\
\hline 5 & 1 & 300 & $>10,000$ & $>167$ \\
\hline 7 & 1 & 100 & $<1,000$ & $<x$ \\
\hline 8 & 25 & $400^{\circ}$ & 01,000 & $\sim 20$ \\
\hline
\end{tabular}

a. Sectable $\mathrm{T}$.

b. At bed top aurface at begining of run (initula bed temperature).

c. No breakthrough observed.

a. Wow not increased further because temperature reached $600^{\circ} \mathrm{C}$.

e. At $<400^{\circ} \mathrm{C}$, sumple 8 was not efficient for fluoxine disposal. 
Tests were made to quantify the effect of temperature on Curine disposal with nomactivated wood charcoal (using charcoal 4). A scruber constating of a 1-1nch-diameter, 4-ft-long glase column rilled wh hemicylindrical stanless steel packing was commected to the outhet of the charcoal colum to trap unreacted

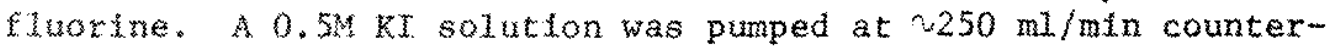
current to the gas flov $\left(N_{2}+N_{2}\right)$ in the scrubber. Saturated $K I$ paper was used to determine that gas leaving the scrubber contained <25 ppw fluorine. Fluorine trapped by $\mathrm{KI}$ in the scrubber was determired why a callorated fuoride-sensituve electrode.

Results (Table TII) indicate that the fluorine-charcoal reaction efficiency increases with temperature. At $5 \%$ fluorine in the tulet gas, only $40 \%$ of the fluorine reacted with charcoal at $200^{\circ} \mathrm{C}$. As indicated in Table IT, a total flow $>25$ times higher than in these tests resulted in no fluorne breakthrough at $300^{\circ} \mathrm{C}$ and $5 \%$ finorine.

The effect of charcoal bed depth on $F_{2}$ disposal rate was not determined in these tests. However, a previous study ${ }^{2}$ demonstrated efficlent $F$ alsposal wh th $25 \%$ fluorine in a heated charcoal bed, 2 inches in dumeter and 2.5 thohes deep, at a linear flow of 150 ftc/ndnute. At $\geqslant 300^{\circ} \mathrm{C}$, the $\mathrm{F}_{2}$-charcoal reaction zone is narrow, and high asposal $x a t e s$ can'be attained until most of the charcoal

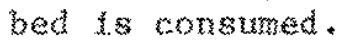

TABLE III

Effect of Temperature on Fluorine Disposal

With honact vated wood Charcoal (Number 4)

\begin{tabular}{|c|c|c|c|}
\hline $\begin{array}{c}F_{2} \\
\text { Concentration, } \\
\text { n }\end{array}$ & $\begin{array}{l}\text { Initial bed } \\
\text { Temperature, } \\
\text { "e }\end{array}$ & $\begin{array}{c}\text { Total oas } \\
\text { Fow }\left(N_{2}+F_{2}\right) \\
c c / m i n \\
\end{array}$ & $\begin{array}{c}F_{2} \\
\text { Reacted With } \\
\text { Charcoal }\end{array}$ \\
\hline 5 & 25 & 395 & 10.3 \\
\hline 10 & 25 & 365 & 42.7 \\
\hline$\sqrt[3]{3}$ & 100 & 395 & 42.5 \\
\hline 30 & .100 & 395 & 42.7 \\
\hline 35 & 200 & 395 & 42.6 \\
\hline 25 & 100 & 400 & 46.2 \\
\hline 5 & 200 & 395 & 81.4 \\
\hline 20 & 200 & 365 & 48.5 \\
\hline$s$ & 200 & 800 & 43.7 \\
\hline 30 & 200 & 800 & 32.9 \\
\hline 15 & 200 & 800 & 33.3 \\
\hline 25 & 200 & 800 & 33.0 \\
\hline
\end{tabular}


Ix all of the tests whi a heated column, the 1/4-inch-diameter axt Ine heated to $2200^{\circ} \mathrm{C}$ to prevent condensation of solld fluorocarbons. The solid residue was a crosslinked fluorocarbon polymet wh a molecular weight $>2000$. The fluorocarbon restdue reles at $130-150^{\circ} \mathrm{C}$ and is sufficiently soluble in "Freon" PCA to be easily removed.

\section{CHARCOAL UTILIZATION EFFICIENCY}

Tests were made to determine utilization efficiency for several nonactryated wood charcoals, and also to determine the amount of condensable fuorocarbons formed per gram of charcoal consumed. Prior to the tests, the charcoals were drfed at $4110^{\circ} \mathrm{C}$. A weighed amount of charcoal was reacted with $25 \%$ fluorine for 1 hr with the colum indtally at $300^{\circ} \mathrm{C}$. Condensable fluorocarbons were collected in an atr-cooled condenser fllled wh coppex shot. At the end of the test, unreacted charcoal was weighed, and the amount of charcoal consumed per gram of fluorine was calculated. The condenser was reweighed to determine the amount of fluorocarbons collected. $A$ porton of the fluorocarbons, other than $\mathrm{CF}_{4}$, and $\mathrm{C}_{2} \mathrm{~F}_{6}$, is moncondensable and passes through the condenser as a white smoke.

Results (Table IV) indicate that charcoals 4 and 6 are most efflcient for reaction wh fluorine. Charcoal efficiency is apparenty unrelated to internal surface area (Tables I and II).

\section{TABLE IV}

Charcoal Consumption and Restive Formation

\begin{tabular}{|c|c|c|c|c|}
\hline $\begin{array}{l}\text { Charcoa } \\
\text { Samplez }\end{array}$ & $\begin{array}{c}\text { Number of } \\
\text { aeterminations }\end{array}$ & $\begin{array}{c}\text { 9 Fa per } \\
\text { a charcoal }\end{array}$ & $\begin{array}{c}\text { Charcoal b } \\
\text { Efficiency, } \\
\%\end{array}$ & $\begin{array}{l}9 \text { Condensables } \\
\text { per } 9 \text { Charcol } \\
\text { Consumed }\end{array}$ \\
\hline 3 & a & 4.5 & 71 & $0.02-0.02$ \\
\hline 4 & $y$ & $5 \times 9$ (avg) & 93 & $0.01-0.03$ \\
\hline 5 & 4 & 4.0 (avg) & 63 & 20.01 \\
\hline 6 & 1 & 6.2 & 98 & 0.03 \\
\hline
\end{tabular}

a. See Table $T$.

b. gased on $6.33 \mathrm{~g} \mathrm{~F}_{2} / \mathrm{g} \mathrm{C}$ for the reaction $2 \mathrm{~F}_{2}+\mathrm{C} \rightarrow \mathrm{CF}$, and assuming we charcoals wre $100 \%{ }^{*} \mathrm{C}$. Obvtows ly the noncarbon impurities in charcoal 4 and 6 react wh ${ }_{2}$; otherwise, the calculated efficiency condd not exceed the carbon content (Table 1 ).

* Du Pont trademark for fluorocarbons 
All of the charcolas genetated a measurable quantity of fluorocarbons that condense at room temperature. The differences in anount of condersables collected (Table TV) are not constiered

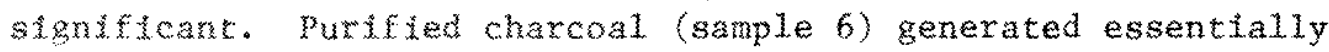
the same anount of condensed residue as the other charcoals even though the cabon content of purtfled charcoal was much higher. The amount of condensable fluorocarbon fomed is atgnificant. A condenser or other collector located downstream of the charcoal trap could collect these fluorocarbons and should prevent line p.uggage if the Iine between the charcoal trap and the collector were heated to $2200^{\circ} \mathrm{C}$. Downdlow traps may be beter than upflow becase or posstble fluorocarbon reflux in the latter.

\section{ANALYSIS OF REACTION PRODUCT GASES}

\section{PROCEDURE}

Gases formed by the reaction of fluorine with nonactivated wood charcoal at $300^{\circ} \mathrm{C}$ indtial trap temperature were investigated. Nonactivated wood charcoal was heated, in the nickel apparatus used in the previous cests, to $300^{\circ} \mathrm{C}$ before fluorine flow was started. Fluorne how was malntalned at $250 \mathrm{cc} / \mathrm{m} / \mathrm{n}$, and $\mathrm{N}_{2}$ flow was adjusted to obtain the destred $F_{2}$ concentration. The wall remperature of the reactor increased from 300 to $430^{\circ} \mathrm{C}$ wh $10 \%$ $\mathrm{F}_{2}$ feed, and from 300 to $565^{\circ} \mathrm{C}$ with $100 \% \mathrm{~F}_{2}$ feed.

Samples of raction product gases were collected in flowthrough tubes and analyzed by gas chromatography. The chromatography was callhrated with $\mathrm{CF}_{4}, \mathrm{C}_{2} \mathrm{~F}_{8}, \mathrm{C}_{3} \mathrm{~F}_{2}, \mathrm{~N}_{2}$, and $\mathrm{CO}_{2}$; sensitivities for these gases were $0.07,0.13,0.25,0.07$, and $0.05 \%$, respectively. A small amount of HF was formed, but no HF analyses were made because the results would depend on the dryness of the charcoal.

\section{RESULTS}

Results of the gas analyses are shown in Table V. Less than a detectable amount of $C F_{4}$ and only a small amount of $C_{2} F_{6}$ were

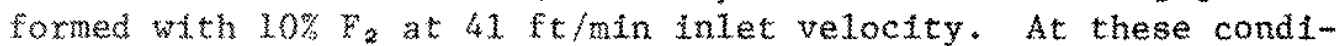
thons, the predominat product is a white fluorocarbon smoke. part of this molke condenses at roon temperature and has been tatented as a crosglinked fluorocarbon polymer with a molecular wetght $>2000$." The amount of $\mathrm{CF}_{4}$ and the $\mathrm{CF}_{4} / \mathrm{C}_{2}$. ratio in the reacton product increased as the fluorine concentration was 
TABLE $V$

Composition of Charcoal Fluorine Reaction Product Gases

Nonactivated Woos Charcoal; Initial Temperature $300^{\circ} \mathrm{C}$

\begin{tabular}{|c|c|c|c|c|c|}
\hline \multicolumn{2}{|l|}{ lnet Gas } & \multirow{2}{*}{\multicolumn{4}{|c|}{ Reaction Product Gases }} \\
\hline Superficlal a & & & & & \\
\hline Helocity, ft/min & $\mathrm{F}_{2}: \mathrm{N}_{2}$ & $C F+4$ & $C_{2} F_{6} x_{2}^{2}$ & 60,25 & $C F_{4} / C_{2} F_{5}$ \\
\hline 43 & $10: 90$ & $<0.07$ & 0.4 & 3.1 & $<0.2$ \\
\hline 16.5 & $25: 75$ & $9.2^{b}$ & 1.1 & 2.3 & 8.4 \\
\hline 5.9 & $70: 30$ & 50.5 & 3,1 & 2.8 & 16.3 \\
\hline $4 \times 2$ & $100: 0$ & $87.7^{\circ}$ & 3.5 & 8.8 & 25.1 \\
\hline
\end{tabular}

a. At $300^{\circ} \mathrm{C}$

b. Avergys of andyses from four Independent tests.

a. Averages of analyses from three independent tests.

Ancreased and velochty was decreased. Both factors tend to increase temperature (more heat of reaction with less gas flow to remove the heat) and dxive the $E_{2}$-charcoal reaction to completton, $1 . e .$, formation of $\mathrm{Cr}_{4}$.

Ruff, 7 reported increased conversion of charcoal to $\mathrm{CF}_{4}$ at higher temperatures and fluorine concentrations, Houston ${ }^{2}$ reported a wight increase in $\mathrm{CF}_{4}$ formation at lower fluorine flows. The compostion of reaction product gases agrees falrly well with those of Ruff, ${ }^{7}$ except no $C_{3} F_{\text {o }}$ was observed in these tests. 


\section{REFERENCES}

3. 3. B. Wavrotel. "Wisposal of Fluorine." ISAEC Report RFP-1200, Dow Chemeat Company, Rocky Flats Division (1968).

2. N. W. Houston. Huomine Disposal Using Charaoat. USAEC Report GA'm-819, Goodyear Atomic Corporation (1960).

3. H. W. Schutd. Destgr and operating Cmiteria for Euorine Disposkt by Reation with Charcoat. NASA Memorandum Memo- $-27-59 E(1959)$.

4. R. S. Standifex, H. N, Robinson, J, R. Sheets, and R. O. Wing. The conversion of putoniw oxide to plutonim Tetrafluoride

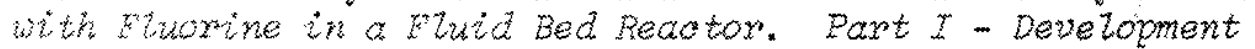
Studies. USAEC Report RFp-1889, Dow Chemtal Company, Rocky Flate Division (1972).

5. H. Fulley and R. L. Hawts. Disposal of whomine at Low concentrations. USAEC Report KY-638, Paducah Gaseous Diffusion plant $(1972)$.

6. O. Rut 0 . Bretschneder, and F. Ebert. "The Reaction products of the Vartous Forms of Carbon with Fluorine." 2. Anorg. Alzgem. Chem, 217, 1 (1934).

7. O. Ruff and $O$. Bretschnelder. "The Composition and Heats of Fomation of the Carbon Fluoride Mixtures Obtained from Nortte and from silfcon Carbide." 2. Anoxg. Allgem. Chem. 277, 19 (1) 33 , 